\title{
Host-parasite interactions between the piranha Pygocentrus nattereri (Characiformes: Characidae) and isopods and branchiurans (Crustacea) in the rio Araguaia basin, Brazil
}

\author{
Lucélia Nobre Carvalho*, ***, Rafael Arruda**, *** and Kleber Del-Claro***
}

\begin{abstract}
In the tropics, studies on the ecology of host-parasite interactions are incipient and generally related to taxonomic aspects. The main objective of the present work was to analyze ecological aspects and identify the metazoan fauna of ectoparasites that infest the piranha, Pygocentrus nattereri. In May 2002, field samples were collected in the rio Araguaia basin, State of Goiás (Brazil). A total of 252 individuals of $P$. nattereri were caught with fishhooks and $32.14 \%$ were infested with ectoparasite crustaceans. The recorded ectoparasites were branchiurans, Argulus sp. and Dolops carvalhoi and the isopods Braga patagonica, Anphira branchialis and Asotana sp. The prevalence and mean intensity of branchiurans (16.6\% and 1.5, respectively) and isopods (15.5\% and 1.0, respectively) were similar. Isopods were observed in the gills of the host; branchiurans were more frequent where the skin was thinner, and facilitated attachment and feeding. The ventral area, the base of the pectoral fin and the gular area were the most infested areas. The correlations between the standard length of the host and the variables intensity and prevalence of crustaceans parasitism, were significant only for branchiurans ( $\mathrm{rs}=0.2397, \mathrm{p}=0.0001 ; \chi 2$ $=7.97 ; \mathrm{C}=0.19$ ). These results suggest that both feeding sites and body size probably play an important role in the distribution and abundance of ectoparasites.
\end{abstract}

Nos trópicos, os estudos sobre a ecologia de interações parasito-hospedeiro são incipientes, sendo a maioria de cunho taxonômico. O principal objetivo do presente estudo foi identificar a fauna metazoária de ectoparasitas e analisar aspectos ecológicos da piranha Pygocentrus nattereri. As coletas foram realizadas em maio de 2002, na bacia do rio Araguaia, GO. Com o auxílio de linha e anzol foram capturados 252 exemplares de $P$. nattereri, dos quais 32,14\% estavam infestados por crustáceos ectoparasitos. As espécies de ectoparasitas registradas foram Argulus sp. e Dolops carvalhoi (Branchiura) e Braga patagonica, Anphira branchialis e Asotana sp. (Isopoda). A prevalência e a intensidade média de branquiúros (16,6\% e 1,5, respectivamente) e isópodos ( $15,5 \%$ e 1,0, respectivamente) foram similares. Isópodos foram observados nas brânquias do hospedeiro; os branquiúros foram mais freqüentes na região ventral, base da nadadeira peitoral e região gular. Nessas áreas, a pele é mais fina, facilitando a fixação e alimentação do parasita. As correlações entre o comprimento padrão do hospedeiro e as variáveis intensidade e prevalência de parasitismo foram significativas apenas para branquiúros ( $\mathrm{rs}=0,2397, \mathrm{p}=0,0001 ; \chi 2=7,97 ; \mathrm{C}=0$, 19 , respectivamente). Os resultados sugerem que os sítios de alimentação e o tamanho corporal dos ectoparasitos provavelmente têm um papel importante na sua distribuição e abundância.

Key words: Serrasalminae, Cymothoidae, Argulidae, ectoparasitism, Amazon basin.

\section{Introduction}

The endoparasite biology of fish is well represented in current literature. However, there is a shortage of data on the infestation and transmission rates of ectoparasite crustaceans of fish in natural conditions (Szalai \& Dick, 1991). There are many crustacean parasites of fish in fresh, brackish and salt water, the majority being ectoparasites (Eiras et al., 2000). Among the several groups of freshwater fish parasites, crustaceans can be pointed out as one of those which cause

\footnotetext{
*Coordenação de Pesquisas em Biologia Aquática (CPBA), C.P. 478, Instituto Nacional de Pesquisas da Amazônia (INPA), 69011-970 Manaus, AM, Brazil (present address). e-mail: carvalholn@yahoo.com.br

**Coordenação de Pesquisas em Ecologia (CPEC), C.P. 478, Instituto Nacional de Pesquisas da Amazônia (INPA), 69011-970 Manaus, AM, Brazil (present address). e-mail: rsarruda@yahoo.com.br

***Instituto de Biologia, C.P. 593, Universidade Federal de Uberlândia, 38400-902 Uberlândia, MG, Brazil. e-mail: delclaro@ufu.br
} 
greater economic loss to fish farms (Pavanelli et al., 1999). About 3000 species of ectoparasite crustaceans have been recognized, and their impact on the fish health can be direct, causing mortality, or indirectly, acting as vectors for diseases, especially those caused by virus (Pavanelli et al., 1999). The main groups of crustacean parasites in fish are Copepoda, Branchiura and Isopoda (Thatcher, 1991; Eiras et al., 2000) and most of the studies accomplished in the Neotropics are related to systematic aspects (Malta, 1982a; Hamman, 1998; Tanaka, 2000).

Isopods have representatives in fresh, brackish and salt water as well in terrestrial environments. They encompass mainly free-living species, but there are also many parasite species of fish and crustaceans (Castro, 1985). A total of 28 ectoparasite isopods (distributed in 12 genera) are known to attack South American freshwater fish (Thatcher, 2000; Thatcher et al., 2002; Thatcher et al., 2003). Most of these isopods belong to the family Cymothoidae and have legs with stout claws that can hold on to any part of a fish (Thatcher, 1991).

The Branchiura subclass is worldwide and includes ectoparasites of fish, and occasionally of reptiles and amphibians (Malta, 1982a). The following genera are known in the Neotropics: Argulus, Dolops and Dipteropeltis (Malta \& Varella, 1983). Branchiurans are small crustaceans (2 to $30 \mathrm{~mm}$ of length) belonging to the family Argulidae, which have their first antennas and both pairs of jawbones adapted for holding on the skin of the fish. They are able to parasitize not only the skin, but also the interior of the gill chamber (Thatcher, 1991).

Piranhas (Characidae: Serrasalminae) are among the main predators of the Neotropical freshwater ecosystems (Almeida et al., 1998). Although they frequently represent a large percentage of the number of individuals and of the total Osteichthyes biomass in the ecosystems where they inhabit
(Mago-Leccia, 1970), their interaction with ectoparasite crustaceans is little studied (Malta 1982a, 1982b, 1984; Malta \& Varella, 1983; Sazima \& Machado, 1990; Hamann 1996, 1998; Tanaka, 2000 and Carvalho et al., 2003). Thus, the main objective of the present study was to identify the metazoan fauna of ectoparasites of the piranha Pygocentrus nattereri Kner, 1860 in lakes and in an oxbow lake of the rio Araguaia basin, State of Goiás, Brazil, and to analyze the ecological aspects of observed interactions.

\section{Material and Methods}

Study area. The piranhas were collected in an oxbow and floodplain lakes during an expedition to São José dos Bandeirantes ( $\left.13^{\circ} 41^{\prime} \mathrm{S}, 50^{\circ} 47^{\prime} \mathrm{W}\right)$, Nova Crixá, State of Goiás, Brazil. The study was carried out in May 2002, when the water level is going down in the rio Araguaia ("vazante" season), a tributary of the rio Tocantins, Amazon basin.

Procedure. The piranhas were caught during the morning and evening periods with three different sizes of fishhooks (numbers 1, 6/0 and 6 Mustad $\odot$ ). Different size fishhooks were used in the attempt to collect varied sizes of $P$. nattereri. Pieces of bovine meat were used as bait. At the exact moment of a capture, each individual had its external surface and the interior of its gills immediately examined with the aid of a magnifying glass and pincers; the locations of the parasites found on the body of the piranhas were recorded (see Carvalho et al., 2003). The ectoparasites were manually collected with the aid of forceps and conditioned in alcohol 70\% (Eiras et al., 2000). After this procedure, the captured piranhas were measured for their standard length $(\mathrm{SL} \mathrm{cm})$.

To verify the distribution of the ectoparasites, the external surface of the body of the fish was divided into: dorsal area,

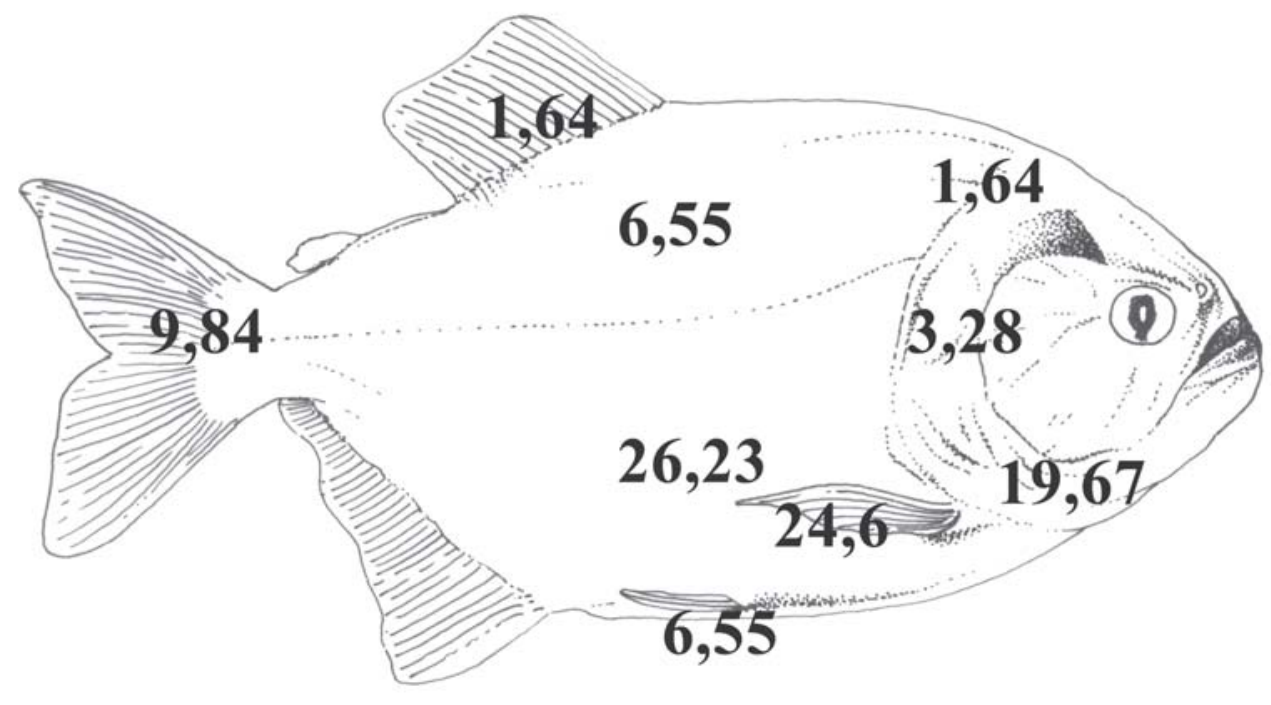

Fig. 1. Relative frequencies (\%) of attachment sites of branchiurans on Pygocentrus nattereri (Serrasalminae) in the Amazon basin. 

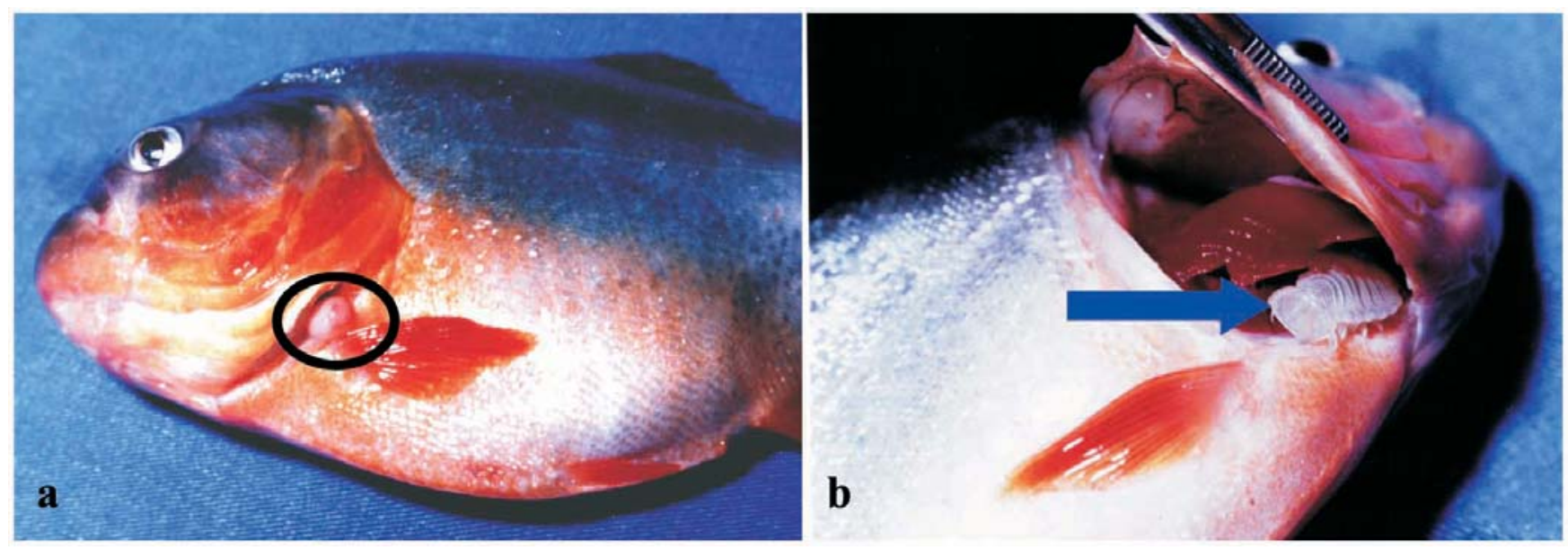

Fig. 2. The circle outlines a tumor (a) observed on Pygocentrus nattereri, possibly caused by the action of the isopod Braga patagonica (b).

ventral area, head (also divided into gullet and upper-head), fins and lateral line. The gills were examined through the mouth and gill openings (see Carvalho et al., 2003). After being examined the piranhas were marked with a notch in the adipose fin, to avoid being reexamined. The adipose fin was chosen for notching due to the high degree of mutilation in the other fins (see Northcote et al., 1987). After the procedure that took from 2 to 3 minutes the fish was released.

The prevalence (number of infested hosts / number of examined hosts $\mathrm{x} 100 \%$ ) and the mean intensity (total number of parasites / number of infested hosts) were calculated according to Bush et al. (1997).

Due to the non-normality of the data concerning the standard length of $P$. nattereri and the intensity of parasitism, the correlation coefficient of Spearman (Siegel, 1981) was applied. In addition, the Contingency Coefficient C (Siegel, 1981) was applied to see if there was any correlation between the standard length of $P$. nattereri and the prevalence. The level of $\mathrm{p}<0.05$ was considered significant in all statistical tests. Voucher specimens of P. nattereri (INPA 20382) and the ectoparasites (INPA 933, 959, 960, 962, 1055 and 1310) were deposited in the Zoological Collection of the Instituto Nacional de Pesquisas da Amazônia.

\section{Results}

The number of specimens of $P$. nattereri captured was 252: 119 were collected in lakes and 133 in an oxbow lake. Of the animals collected, $32.14 \%$ presented infestation by ectoparasites crustacean, with a mean intensity of 1.3 and with a range that varied from 1 to 5 ectoparasites per host.

The fauna of crustacean ectoparasites observed in $P$. nattereri was composed of either branchiurans or isopods; only three hosts presented both ectoparasites. The branchiuran species recorded and their respective frequency were: Argulus sp. (62.16\%) and Dolops carvalhoi Lemos de Castro,
1949 (37.84\%). The isopod species and respective frequency were: Braga patagonica Schiödte \& Meinert, 1884 (88.89\%), Anphira branchialis Thatcher, 1993 (8.89\%) and Asotana sp. (2.22\%).

The body parts that showed higher frequencies of branchiuran distribution in $P$. nattereri were, in decreasing order: ventral area, base of the pectoral fin, gular area, tail fin, dorsal area and ventral fin, inside the gill chamber, and head and dorsal fin (Fig. 1).

The isopods were located in the gills and at least one individual per gill chamber was found in $90 \%$ of the infested piranhas. Pairs of adult isopods were also observed, each individual occupying one side of the gill chambers $(n=4)$. Exceptions occurred when one adult and one young individual of $B$. patagonica were found in the same side of the gill chamber $(n=2)$, and when one adult was found on the tail fin. One tumor caused by isopods was observed in the operculum (Fig. 2). The prevalence and mean intensity values were similar for branchiurans and isopods in both lakes and oxbow lake (Table 1).

The standard length of $P$. nattereri varied from 9.0 to $25.0 \mathrm{~cm}(13.23 \pm 2.4 ; \mathrm{X} \pm 1 \mathrm{SD})$. The correlation between the standard length of the host and the branchiuran intensity ( $\mathrm{rs}=0.2397, \mathrm{p}=0.0001$ ) was significant, while that between standard length and the isopod intensity ( $\mathrm{rs}=-0.0387, \mathrm{p}=$

Table 1. Prevalence (Prev. - \%) and mean intensity (Int.) of infestation by ectoparasite crustaceans of Pygocentrus nattereri sampled from lakes and an oxbow lake at the rio Araguaia, State of Goiás, Brazil, May 2002.

\begin{tabular}{|c|c|c|c|c|c|c|c|c|c|}
\hline \multirow{3}{*}{ Ectoparasites } & \multicolumn{9}{|c|}{ Environments } \\
\hline & \multicolumn{3}{|c|}{ Oxbow lake } & \multicolumn{3}{|c|}{ Lakes } & \multicolumn{3}{|c|}{ Total } \\
\hline & Prev. & Int. & Range & Prev. & Int. & Range & Prev. & Int. & Range \\
\hline Isopoda & 15.8 & 1.2 & $0-2$ & 15.0 & 1.0 & $0-1$ & 15.5 & 1.0 & $0-2$ \\
\hline Branchiura & 18.0 & 1.6 & $0-5$ & 15.0 & 1.2 & $0-3$ & 16.6 & 1.5 & $0-5$ \\
\hline
\end{tabular}


0.289) was not (Fig. 3). The mean standard length of $P$. nattereri and prevalence of parasitism was significant only for branchiurans $(\chi 2=7.97 ; \mathrm{C}=0.19)$.

\section{Discussion}

The occurrence of Braga patagonica and Asotana sp. on $P$. nattereri represent new records of host-parasite interaction (Thatcher, 1991, 1993, 2000). Hosts of Anphira branchialis, which include $P$. nattereri, were listed by Thatcher (1993). The branchiurans Dolops carvalhoi and two species of Argulus were also recorded as parasites of $P$. nattereri (Thatcher, 1991; Carvalho et al., 2003).

Studying the parasitic fauna of the piranha Serrasalmus spilopleura in lakes of Argentina, Hamann (1996) observed that the branchiuran Dolops aff. bidentata and the isopod Braga fluviatilis showed competition for habitat (host). In other words, when the density of one species increased, the density of the other decreased and vice-versa. The prevalence of branchiurans in $P$. nattereri obtained in this study was three times smaller than that observed in rivers and lakes of the Pantanal, the Brazilian wetlands, where isopods were not observed (Carvalho et al., 2003). So, the results obtained for the rio Araguaia suggest that the low branchiuran prevalence can be a result of negative interactions, such as competition. It should be emphasized that $B$. patagonica occupied only the gill chamber, while $B$. fluviatilis usually occupies the body surface of its host, $S$. spilopleura.

The base of the pectoral fin and the gular and ventral areas of $P$. nattereri showed higher branchiuran frequencies. According to Carvalho et al. (2003), the ventral and gular areas of $P$. nattereri showed the major branchiuran frequencies. The areas have the thinnest skin compared to other body parts, which would facilitate in the attachment and feeding of the branchiurans. Thatcher (1991) pointed

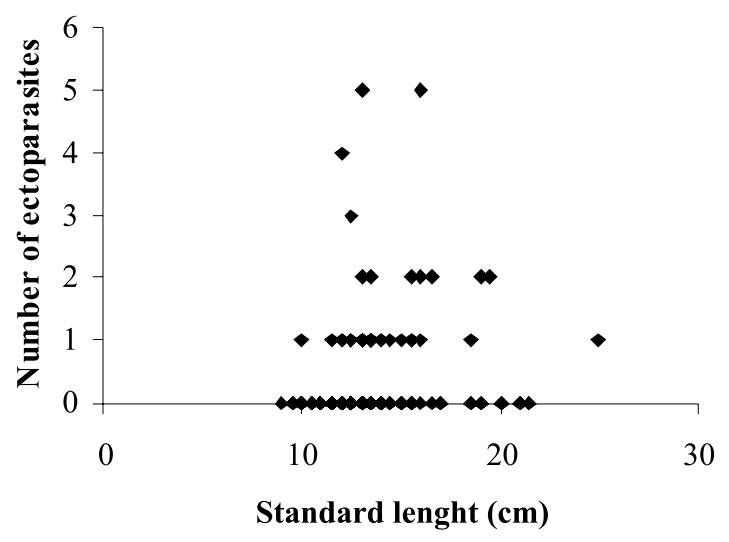

Fig. 3. Correlation between the standard length of Pygocentrus nattereri and the number of branchiurans (intensity of infestation) in lakes and an oxbow lake at the rio Araguaia, State of Goiás, Amazon basin. ( $\mathrm{rs}=0.2397, \mathrm{p}=0.0001)$. out that the Argulidae are skilled at sliding around the surface of the fish in search of an appropriate feeding site, selecting places that have fewer scales (such as the base of the fins).

The feeding activity of the Cymothoidae isopods in the gill chamber can cause damage to the host in several ways, such as tissue and blood loss, reduction of the gill filaments, and reduction of the breathing efficiency. The presence of these ectoparasites also affects the metabolism, and can cause a decrease in the growth rate (Thatcher, 1991, 1993; Thatcher $\&$ Neto, 1994). Thatcher (1993) revealed that the Cymothoidae Anphira branchialis can also cause the growth of tumors in the piranha Serrasalmus sp. In the present study, a tumor growth was observed in the operculum of $P$. nattereri, probably caused by $B$. patagonica.

The slightly higher parasitism rate observed in the oxbow lake may be related to the water flow through that environment. Carvalho et al. (2003) observed higher rates of parasitism in lotic environments when compared to lakes and suggested that fish hosts may be used by parasites for riding. Branchiurans seems to be poor swimmers and may stay attached to the hosts for longer periods when in lotic habitats, which would help avoid being swept by the currents. The weak correlation between the standard length of $P$. nattereri and branchiuran intensity showed that many individuals host few or no branchiurans, while only a few fishes are intensely infested. This result fits in with the aggregation tendency, one of the most common aspects of infections by metazoan parasites. Thus, the host population has many individuals hosting few or no parasites and a few showing high infestations (Crofton, 1971; Boxshall, 1974; Anderson \& Gordon, 1982).

Hamann (1998) observed that in northeast Argentina there is significant correlation between isopods (B. fluviatilis) and the total length of the host ( $S$. spilopleura), showing that the maximum peaks of infestation are related to the length of the host. In the present study, there was no significant correlation between the standard length of the host and the number of isopods. This result reflects the observation that $90 \%$ of the piranhas contained just one isopod and this was located in the gill chamber, unlike $B$. fluviatilis, which usually occupies the body surface of its host.

The correlation between the standard length of $P$. nattereri and the ectoparasitism prevalence was significant only for branchiurans. Carvalho et al. (2003) did not find correlation between the standard length of $P$. nattereri and the branchiuran incidence in the Pantanal. They argued that the branchiurans probably do not actively select larger hosts, but that larger hosts are probably exposed to parasitism for a longer period of time, which would increase their chance of contracting these parasites. Their larger corporal surface also increases the available resources for the parasites. Zelmer \& Arai (1998) showed in a study on the perch Percaflavescens that the effects of age and of host size can contribute to the aggregation of parasites.

Both feeding sites and body size probably play an 
important role in the distribution and abundance of ectoparasites. Since the isopods have a larger body size than the branchiurans, and since they feed only in the gill chamber, their feeding site is much smaller than that of the branchiurans (the whole body surface of the host). Thus, the host can have a much greater abundance of branchiurans than of isopods.

\section{Acknowledgements}

The authors are very thankful to Ricardo Massato Takemoto, Angela M. B. Varella and José C. O. Malta for the identification of the ectoparasites; André Quagliatto for the complete logistic support, Daniela A. V. Murari for the help in the field; Jamil Tannús Neto for the drawing of the piranha; Oswaldo Marçal Júnior, Angela M. B. Varella and Jansen Zuanon for the critical reading of the manuscript. Kleber DelClaro thanks to CNPq and Fapemig for research grants.

\section{Literature cited}

Almeida, V. L. L., N. S. Hahn \& C. S. Agostinho. 1998. Stomach content of juvenile and adult piranhas (Serrasalmus marginatus) in the Paraná Floodplains, Brazil. Studies on Neotropical Fauna and Environment, 33: 100-105.

Anderson, R. M. \& D. M. Gordon. 1982. Processes influencing the distribution of parasite numbers within host populations with special emphasis on parasite-induced host mortalities. Parasitology, 85: 373-398.

Boxshall, G. A. 1974. The population dynamics of Lepeophtheirus pectoralis (Müller): dispersion pattern. Parasitology, 69: 373-390.

Bush, A. O., K. D. Lafferty, J. M. Lotz \& A. W. Shostak. 1997. Parasitology meets ecology on its own terms: Margolis et al. revisited. Journal of Parasitology, 83: 575-583.

Carvalho, L. N., K. Del-Claro \& R. M. Takemoto. 2003. Hostparasite interaction between branchiurans (Crustacea: Argulidae) and piranhas (Osteichthyes: Serrasalminae) in the Pantanal wetland of Brazil. Environmental Biology of Fishes, 67: 289-296.

Castro, A. L. 1985. Manual de identificação de invertebrados límnicos do Brasil: Isopoda. Brasília, CNPq, 20p.

Crofton, H. D. 1971. A quantitative approach to parasitism. Parasitology, 62: 179-193.

Eiras, J. C., R. M. Takemoto \& G. C. Pavanelli. 2000. Métodos de estudo e técnicas laboratoriais em parasitologia de peixes. Paraná, EDUEM, Nupélia, 173p.

Hamann, M. I. 1996. Fauna parasitaria de Serrasalmus spilopleura Kner, 1860 en ambientes leníticos de la província de Corrientes, Argentina. Revista de Ictiologia, 4: 11-17.

Hamann, M. I. 1998. Aspectos ecológicos de la relácion parasitaria entre juveniles de Braga fluviatilis Richardson, 1911 (Crustacea, Cymothoidae) y Serrasalmus spilopleura Kner, 1860 (Pisces, Characidae) en poblaciones naturales del Nordeste Argentino. Physis, 55: 15-22.
Mago-Leccia, F. 1970. Estudios preliminares sobre la ecología de los peces de los llanos. Acta Biológica Venezuelana, 7: 71-102.

Malta, J. C. O. 1982a. Os argulídeos (Crustacea: Branchiura) da Amazônia Brasileira. Aspectos da ecologia de Dolops discoidalis Bouvier, 1899 e Dolops bidentata Bouvier, 1899. Acta Amazonica, 12(3): 521-528.

Malta, J. C. O. 1982b. Os argulídeos (Crustacea: Branchiura) da Amazônia Brasileira, 2. Aspectos da ecologia de Dolops geagy Bouvier, 1897 e Argulus juparanaensis Castro, 1950. Acta Amazonica, 12(4): 701-705.

Malta, J. C. O. 1984. Os peixes de um lago de várzea da Amazônia Central (Lago Janauacá, Rio Solimões) e suas relações com os crustáceos ectoparasitas (Branchiura: Argulidae). Acta Amazonica, 14 (3-4): 355 372.

Malta, J. C. O. \& A. Varella. 1983. Os argulídeos (Crustacea: Branchiura) da Amazônia Brasileira 3. Aspectos da ecologia de Dolops sriata Bouvier, 1899 e Dolops carvalhoi Castro, 1949. Acta Amazonica, 13(2): 299306.

Northcote, T. G., M. Arcifa \& O. Froehlich. 1987. Fin-feeding by the piranha (Serrasalmus spilopleura Kner): the cropping of a novel renewable resource. Proceedings of the 5 th Congress European of Ichthyologists Stockholm, 1985, pp.133-143.

Pavanelli, G. C., J. C. Eiras \& R. M. Takemoto. 1999. Doenças de peixes: profilaxia, diagnóstico e tratamento. Paraná, EDUEM, Nupélia, 264p.

Sazima, I. \& F. A. Machado. 1990. Underwater observations of piranhas in Western Brazil. Environmental Biology of Fishes, 28: 17-31.

Siegel, S. 1981. Estatística não-paramétrica, para as ciências do comportamento. São Paulo, Ed. McGraw-Hill do Brasil, $350 \mathrm{p}$.

Szalai, A. J. \& T. A. Dick. 1991. Evaluation of gill nets, fyke nets, and mark-recapture methods to estimative the number of Hirudinea and Crustacea on fish. Journal of Parasitology, 77: 914-922.

Tanaka, L. K. 2000. Aspectos ecológicos dos parasitos de Serrasalmus marginatus Valenciennes, 1847 e Serrasalmus spilopleura Kner, 1860 (Characiformes, Serrasalmidae) do rio Baía, planície de inundação do alto rio Paraná, MS. Unpublished M.Sc. Thesis, Universidade Estadual de Maringá, Maringá. 32p.

Thatcher, V. E. 1991. Amazon Fish Parasites. Amazoniana, 11(3/4): 263-572.

Thatcher, V. E. 1993. Anphira branchialis gen. et sp. nov. (Crustacea, Isopoda, Cymothoidae) a gill cavity parasite of piranhas (Serrasalmus spp.) in the Brazilian Amazon. Acta Amazonica, 23 (2-3): 297-307.

Thatcher, V. E. 2000. The isopod parasites of South American Fishes. Pp. 193-226. In: G. Salgado-Maldonado, A. N. García Aldrete \& V. M. Vidal-Martínez (Eds.). Metazoan parasites in the Neotropics: a systematic and ecological perspective. Instituto de Biologia UNAM, México. 310 p. 
Thatcher, V. E., L. P. C. Lopes \& O. Froehlich. 2002. Riggia acuticaudata sp. nov. (Isopoda, Cymothoidae) from the body cavity of a freshwater fish of Mato Grosso do Sul State, Brazil. Revista Brasileira de Zoologia, 19 (Supl. 2): 195-201.

Thatcher, V. E., L. P. C. Lopes \& O. Froehlich. 2003. Riggia cryptocularis sp. nov. (Isopoda, Cymothoidae) from the body cavity of a freshwater fish of Mato Grosso do Sul State, Brazil. Revista Brasileira de Zoologia, 20(2): 285-289.

Thatcher, V. E. \& J. B. Neto. 1994. Diagnóstico, prevenção e tratamento das enfermidades de peixes neotropicais de água doce. Revista Brasileira de Medicina Veterinária, 16 (3): 111-127.
Zelmer, D. A. \& H. P. Arai. 1998. The contributions of host age and size to the aggregated distribution of parasites in yellow perch, Perca flavescens, from Garner Lake, Alberta, Canada. Journal of Parasitology, 84: 24-28.
Received March 2004

Accepted June 2004 